\title{
Population fluctuations of the main pests infesting kidney beans and its relation with some weather factors
}

\author{
Gamila Sh. Selem ${ }^{1}$; Heba A. Ismail ${ }^{2}$ and Abd-Elsamad, A. A. ${ }^{2}$ \\ ${ }^{1}$ Plant Protection Dept., Fac. Of Agric., Zagazig Univ., Egypt. \\ ${ }^{2}$ Plant Protection Res. Inst. Agric. Res. Center, Dokki, Giza, Egypt. \\ Coressponding author : gamilashehata@yahoo.com
}

\begin{abstract}
The present work was conducted during the two summer successive seasons, 2014 and 2015 to study the population fluctuations of the red spider mite Tetranychus urticae Koch, cow pea aphid Aphis craccivora Koch, American serpentine leaf miner Liriomyza trifolii (Burgess), cotton whitefly Bemesia tabaci (Genn.), potato leafhopper Empoasca decipiens (Paoli), cotton thrips Thrips tabaci L. and cotton aphid Aphis gossypii Glover infesting kidney bean plants at Abo Hammad district, Sharkia governorate, Egypt. The aforementioned pests were collected by two different methods from kidney bean plantation using plant samples and sweeping net. The obtained results showed that the plant samples proved to be the best method to investigate mite, aphids, leaf miner (larvae), whitefly and thrips pests, while sweeping net proved to be the best technique to investigate the potato leafhoppers. The seasonal abundance of $T$. urticae and L. trifolii showed three peaks of population density, while the results of A. craccivora, B. tabaci, E. decipiens on kidney bean plants showed two peaks of population density during two seasons. On the other hand T. tabaci recorded one peak of population density. Regarding to the effect of mean temperature and atmospheric relative humidity as well as their total combined effect on the numbers of certain investigated pests, it is obvious that the effect was clear.
\end{abstract}

Key Words: Population fluctuations, Tetranychus urticae Koch, Aphis craccivora Koch Liriomyza trifolii (Burgess), Kidney beans (Phaseolus vulgaris $\mathrm{L}$.).

\section{Introduction}

Kidney bean (Phaseolus vulgaris L.) is considered one of the most important leguminous vegetable crops in Egypt. It has a great economic importance because of its use for local and global trading. It occupies the second grade in export among the legume crops, according to the report of the Department of Agricultural Economy, Ministry of Agriculture (2003). Green beans have been reported to contain $6.2 \%$ protein, $0.2 \%$ fat, and $63 \%$ carbohydrate (Sandsted, 1980) while kidney bean seeds are rich in $A, B$ and $D$ vitamins, and protein content of between $17-35 \%$ (Piha \& Munns, 1987).

In Egypt kidney bean usually infested by different pests that cause considerable damage in both quantity and quality of pods, viz, aphids, leaf miner, leafhoppers, thirps and red spider mite which causes serious damage to plant and subsequently yield (Schuster and Everett, 1983; Parrella et al., 1985; Abd El-Gawwad, 2008 and Saleh, 2011). This study aimed to evaluate the population fluctuations of the main pests infesting kidney beans (Phaseolus vulgaris L.) and also study the combined effects of principle climatic factors on tested pests and utilize the obtained results in developing the integrated pest management (IPM) programs against these pests on kidney bean plants through the effect of both temperature and relative humidity on these pests.

Materials and Methods
These experiments were carried out during two growing summer seasons of kidney bean plants (2014 and 2015). An experimental area of about 1/4 faddan was divided into three replicates (each replicate about $350 \mathrm{~m}^{2}$ ). An experimental area was designed according to a complete randomized block design and sown by kidney bean seeds (Phaseolus vulgaris L.) variety Giza- 6 on $1^{\text {st }}$ week of March at Abo Hammad district, Sharkia governorate, Egypt. Two different sampling techniques for investigating of the main infesting kidney bean plants were used when the age of plants reached about 21 days and continued weekly throughout the growing season until the second week of June. These points were studied as followed by:

\section{1- Sampling techniques}

- Plant samples: samples of 25 leaves were picked at early morning randomly at weekly from each replicate representing the different plant levels. Samples were put in paper bags and transferred to the laboratory in the same day for examination and counting the number of each investigated pest by aid of stereoscopic microscope. A simple apparatus was used for counting aphid populations, which was consisted of a wooden box, a white cardboard paper divided into $3 \mathrm{~cm}$ apart columns, was put in the bottom, on which a glass plate was placed and the upper surface of the glass plate was allowed to be wet with fine droplets of water to reduce the movement of counted aphids. The leaves were carefully shaken on the plate and the aphid insects were counted, using a small brush, in each column (Abd Allah, 1984; Hegab et al., 1987 and Hashem, 2005). 
- Sweeping net: To evaluated population fluctuation activity, a sweeping net technique was applied. For this purpose a sweeping net $35 \mathrm{~cm}$ diameter and $60 \mathrm{~cm}$ in depth of the conical fine muslin and a long wooden handle $(1.6 \mathrm{~m})$ was used. Each sample represented by 100 double strokes taken weekly from each replicate both diagonal directions randomly of the experimental area. Sweeping net was the best technique to investigate the potato leafhoppers. Captured insects were transferred in well tied plastic sacs to the laboratory for examination and counting.

\section{2- Influence of daily mean temperature and relative} humidity on the seasonal abundance of the main pests of kidney bean plants:-

The daily mean of minimum, maximum temperature and relative humidity were obtained from the Meteorological Department of the Agricultural Research Station at Sharkia governorate. Records of these factors were recalculated to get the daily averages within a week corresponding with sampling dates. The total numbers were registered and the number mean, peaks of different pests were calculated. The obtained data were statistically analysis by simple correlation ( $\mathrm{r}$ ), the partial regression (b) and coefficient of determination (C.D.) were calculated between each of temperature, relative humidity (R.H \%) and the weekly numbers of these pests according to Fisher (1950) and Snedecor (1966).

\section{Results and Discussion}

\section{The main pests attacking kidney bean(Phaseolus vulgaris $\mathbf{L}$.) plants:-}

The obtained data in Table (1) recorded the main pests during two successive summer seasons 2014 and 2015. A total number of 4131.92 individuals/ 25 leaf which represented by four order, six family, six genera and seven species. Restricted identification and counting of the genera and species during 2014 and 2015 proved to include the red spider mite, T. urticae Koch total numbers of 1028.97, 777.64 individuals/25 leaf and cow pea aphid, A. craccivora Koch total numbers of $694.25,523.26$ individuals/25 leaf, American serpentine leaf miner, L. trifolii total numbers of $211.28,178.96$ individuals/25leaf, the cotton whitefly, B. tabaci immature stages 101.97 and 88.97 individuals/25leaf, potato leafhopper $E$. discipiens of $214.92,142.6$ individuals/25leaf, the cotton thrips, $T$. tabaci L. of 64.3 and 47.29individuals/25leaf and cotton aphid A. gossypii of 30.94 and 26.57 individuals/ 25leaf, respectively. These results are in agreement with those obtained by Abo-zaid (2011) who showed that the main pests infesting green bean plants during three successive seasons 2008, 2009 and 2010 in summer plantation were $T$. urticae which the most abundant pest in first season, followed by L. trifolii, A. craccivora, B. tabaci, E. discipiens.

Table 1. Total number of the main pests recorded on kidney bean plants during summer seasons, 2014 and 2015 at Abo Hammad district, Sharkia governorate, Egypt.

\begin{tabular}{|c|c|c|c|c|c|}
\hline \multirow[b]{2}{*}{ Pest species } & \multicolumn{2}{|c|}{2014} & \multicolumn{2}{|c|}{2015} & \multirow{2}{*}{$\begin{array}{l}\text { General } \\
\text { total } \\
\text { numbers }\end{array}$} \\
\hline & $\begin{array}{l}\text { Plant } \\
\text { samples }\end{array}$ & $\begin{array}{l}\text { Sweeping } \\
\text { net }\end{array}$ & $\begin{array}{l}\text { Plant } \\
\text { samples }\end{array}$ & $\begin{array}{l}\text { Sweeping } \\
\text { net }\end{array}$ & \\
\hline T. urticae & 1028.97 & - & 777.64 & - & 1806.61 \\
\hline A. craccivora & 668.95 & 25.3 & 506.96 & 16.3 & 1217.51 \\
\hline L. trifolii & 211.28 & - & 178.96 & - & 390.24 \\
\hline B. tabaci (immature stages) & 101.97 & - & 88.97 & - & 190.94 \\
\hline E. decipiens & 76.97 & 137.95 & 49.63 & 92.97 & 357.52 \\
\hline Thrips tabaci & 64.3 & - & 47.29 & - & 111.59 \\
\hline A. gossypii & 27.64 & 3.3 & 22.28 & 4.29 & 57.51 \\
\hline Total & 2180.08 & 106.55 & 1671.73 & 70.54 & 4131.92 \\
\hline
\end{tabular}

\section{Population abundance of the main pests attacking kidney bean plants:-}

\section{a) The red spider mite, $T$. urticae Koch}

Data presented in Table (1) indicated that total numbers of $1028.97 \& 777.64$ individuals were recorded during season 2014 and 2015, respectively. Fig. $(1,2)$ showed the activity period of $T$. urticae had three peaks, the first one occurred in the $2^{\text {nd }}$ week of April with the mean number of 29.66 and 16.66 individuals / 25leaf at the mean of $19.4{ }^{\circ} \mathrm{C} ., 17.3{ }^{\circ} \mathrm{C}$. with $64.7 \%$ and $66.7 \%$ R.H. for the two seasons of study, respectively. The second peak occurred in the fourth week of April with the mean number of 52.33 and 30.33 individuals / 25leaf at the mean of $18.4^{\circ} \mathrm{C}$., $18.1{ }^{\circ} \mathrm{C}$. with $65.6 \%$ and $60.9 \%$ R.H. for the two seasons, respectively. While the third peak occurred in the first week of June with the mean number of 381 and 307.66 individuals/25leaf at the mean of 24.9 ${ }^{\circ} \mathrm{C}$., $25.7^{\circ} \mathrm{C}$. with $57.0 \%$ and $57.1 \%$ R.H. for the two seasons. These results are in agreement with that obtained by Abdel- Gawwad (2004) who showed that the population density of $T$. urticae was the main pest within Tetranychidae Family infesting common bean plants. 
b) The cow pea aphid, $A$. craccivora Koch:

As shown in Fig. $(1,2)$ the population density recorded two peaks the first one occurred in the third week of April (252.66 and 175insects /25leaf) at the mean of $19.4^{\circ} \mathrm{C} ., 16.2^{\circ} \mathrm{C}$. with $64.7 \%$ and $69.0 \%$ R.H. while, the second one occurred in the fourth week of May (48.33 and 32.66 insects / 25 leaf) at the mean of $25.0^{\circ} \mathrm{C}$., $25.3{ }^{\circ} \mathrm{C}$. with $59.0 \%$ and $59.4 \%$ R.H. for the two seasons, respectively. These results agree with the findings of El -Gindy (2002) and Hashem (1997) who mention that both of $A$. craccivora and $A$. gossypii has two generations of bean plants.
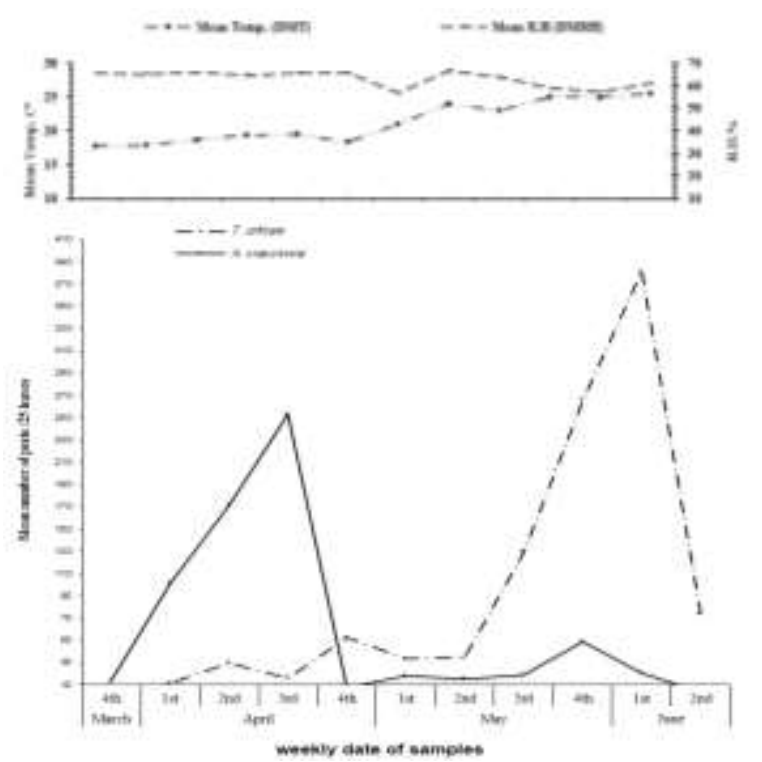

Fig. (1) :Population density of T. urticae and A. craccivora infesting kidney bean plants using plant samples method during summer season 2014 at Sharkia governorate.
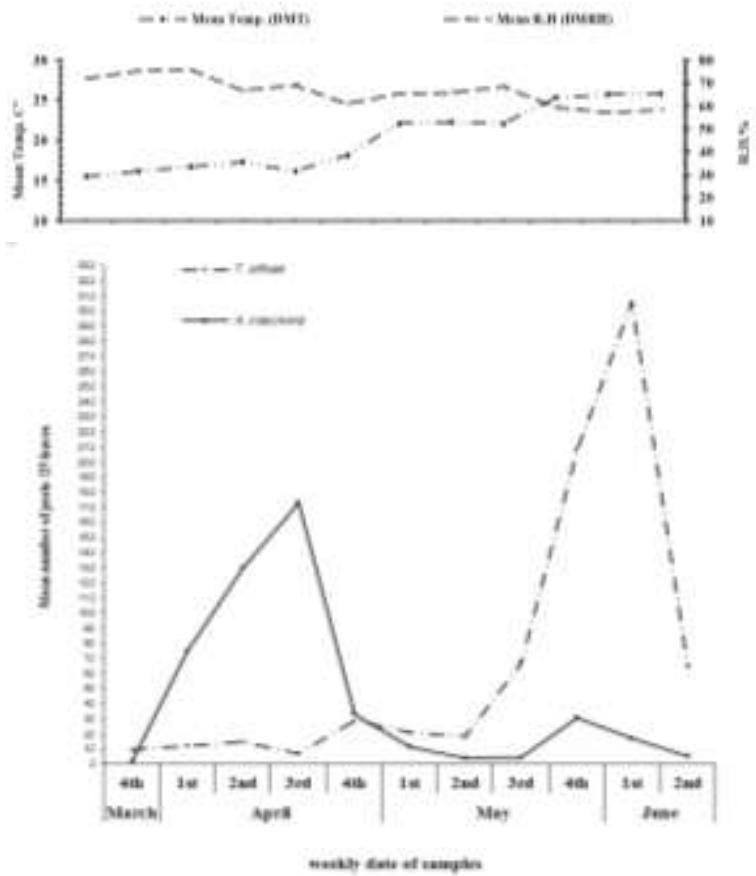

Fig. (2) :Population density of T. urticae and A. craccivora infesting kidney bean plants using plant samples method during summer season 2015 at Sharkia governorate.

\section{c) The American serpentine leaf miner, L. trifolii} (Burgess)

Data in Fig. $(3,4)$ revealed that the population of $L$. trifolii was higher during the first season than the second one, the population density recorded three peaks. The first one occurred in the $2^{\text {nd }}$ week of April with the mean number of 24.33 and 21.33 larvae/ 25 leaf at the mean of $19.4^{\circ} \mathrm{C}$., $17.3{ }^{\circ} \mathrm{C}$. with $64.7 \%$ and $66.7 \%$ R.H. for the two seasons, respectively. The second peak occurred in the first week of May with the mean number of 32.33 and 27 larvae / 25leaf at the mean of $21.0^{\circ} \mathrm{C}$., $22.1^{\circ} \mathrm{C}$. with $56.7 \%$ and $64.4 \%$ R.H. for the two experimented seasons, respectively. While the third peak occurred in the first week of June with the mean number of 30.66 and 25 larvae / 25leaf at the mean of $24.9^{\circ} \mathrm{C}$., $25.7{ }^{\circ} \mathrm{C}$. with $57.0 \%$ and $57.1 \%$ R.H. for the two seasons. These results are in agreement with those obtained by Abd El-Gawwad (2008) who indicated that the mean number of $L$. trifolii population on kidney bean plants reached its maximum on April during the two seasons (2005 and 2006) in the summer plantation.

d) The cotton whitefly, B. tabaci (immature stages)

Two peaks were recorded for the population density. The first one occurred in the first week of May with the mean number of 15 and 12.66 insects / 25 leaf at the mean of $21.0^{\circ} \mathrm{C}$., $22.1{ }^{\circ} \mathrm{C}$. with $56.7 \%$ and $65.4 \%$ R.H. The second peak occurred in the first week of June with the mean number of 21.33 and 17 insects / 25leaf at the mean of $24.9^{\circ} \mathrm{C}$., $25.7^{\circ} \mathrm{C}$. with $57.0 \%$ and $57.1 \%$ R.H. for the two seasons, respectively, in Fig. $(3,4)$. These results agree with the findings of EI-Sayed $\boldsymbol{e} \boldsymbol{t} \boldsymbol{a l}$. (1991) who showed that high rate of infestation with B. tabaci immature stages on bean leaf in all plantations (early summer, summer and winter). Also El-Khayat et al. (1994) estimated the relative population density of $B$. tabaci stages on leaves of summer vegetable crops at two locations in Qalubiya Governorate (Moshtohor and, El-Kanater ElKhaireia).

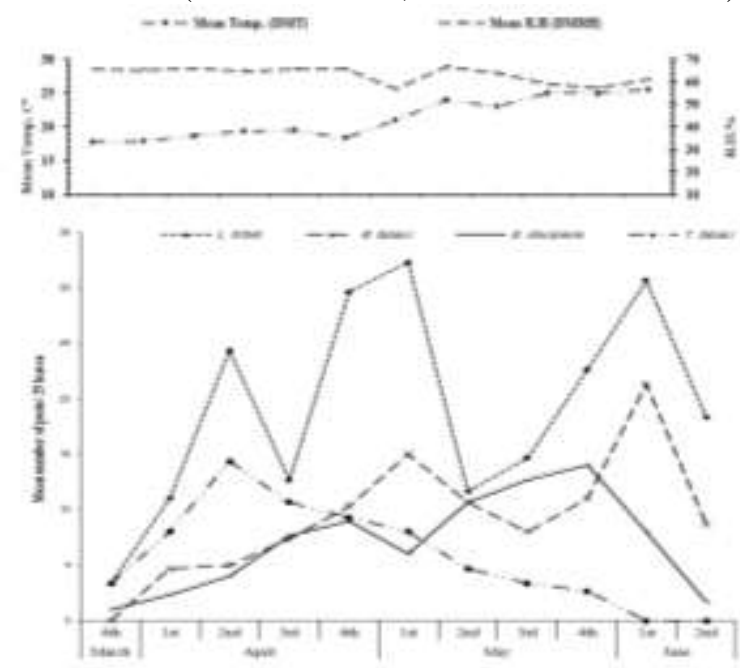

$$
\text { menty sole se enmples }
$$

Fig. (3) :Population density of L. trifolii, B. tabaci, E. discipiens and T. tabaci infesting kidney bean plants using plant samples method during summer season 2014 at Sharkia governorate. 

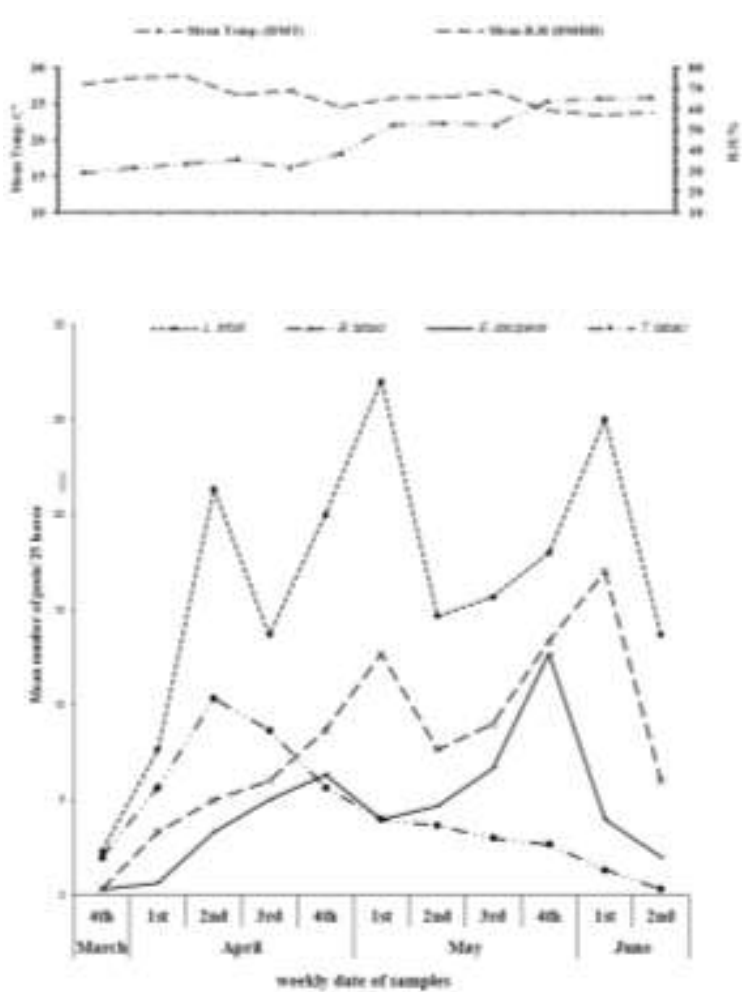

Fig. (4) :Population density of L. trifolii, B. tabaci, E. discipiens and T. tabaci infesting kidney bean plants using plant samples method during summer season 2015 at Sharkia governorate.

\section{e) The potato leafhopper, $E$. decipiens}

Data of the seasonal population abundance of $E$. decipiens on kidney bean plants in 2014 and 2015 are shown in Fig. (3,4). Two peaks of population density were recorded for E. decipiens. The first one occurred at the fourth week of April with a mean number of 9 and 6.33individuals/sample at mean of $18.4^{\circ} \mathrm{C}, 18.1^{\circ} \mathrm{C}$ with $65.6 \%$ and $60.9 \%$ R.H. for the two seasons, respectively. The second peak occurred at the fourth week of May with a mean number of 14 and 12.66 individuals/sample at a mean of $25.0^{\circ} \mathrm{C}$ and $25.3{ }^{\circ} \mathrm{C}$ with $59.0 \%$ and $59.4 \%$ R.H. for the two seasons respectively. These results agree with the findings of Mahmoud et al. (2011) who studied population fluctuation of the leafhopper, E. decipiens (Paoli) on some plantations (broad bean, green bean, pea, lupine, potato and squash) during winter season 2008-2009 at El-Kanater El-Khairia farm, Kalubia Governorate. The data indicated that E. decipiens had two peaks during its winter activity.

\section{f) The cotton thrips, T. tabaci :}

The population density recorded one peak the occurred in the second week of April with the mean number of 14.33 and 10.33 insects / 25leaf at the mean of $19.4^{\circ} \mathrm{C} ., 17.3^{\circ} \mathrm{C}$. with $64.7 \%$ and $66.7 \%$ R.H. in Fig. $(3,4)$. These results are in agreement with those obtained by Amaar et al. (2014) who surveyed the most pests infesting green bean plants during 2011\&2012 growing seasons at Qalubiya governorate and recorded that T. tabaci as one of the main insect pests of these plants. In conclusion, the heaviest infestation levels of the studied pests on kidney bean plants coincided with temperature and relative humidity.

\section{3) Influence of daily mean temperature (DMT) and relative humidity (DMRH) on the activity of the main pests:}

Data presented in Table (2) showed the simple correlation (r), simple partial regression (p) coefficients and coefficient of determination (C.D.) for relationship between the daily mean temperature (DMT), daily mean relative humidity (DMRH) and the main pests activity attacking kidney bean plants during the two successive seasons 2014 and 2015.

a) $\boldsymbol{T}$. urticae : The effect of (DMT) on the activity of $T$. urticae had significant positive $\left(\mathrm{r}_{1}=\right.$ $0.6701^{*}$ and $0.7082^{*}$ ) during 2014 \& 2015 respectively. On the other hand, the relationship between (DMRH) and the mean number of this pest had significant negative effect in both seasons $\left(\mathrm{r}_{2}=-\right.$ $0.6631^{*}$ and $\left.-0.6559^{*}\right)$ during 2014 \& 2015 respectively. The coefficient of determination percentage (C.D.\%) of relationship between these ecological factors were responsible as both of $56.88 \%$ and $52.7 \%$ effects on the populations of $T$. urticae throughout both seasons, respectively in Table(2). These results are in disagreement with those obtained by Amaar et al. (2014) revealed that minimum, maximum temperature had insignificant negative effects on seasonal fluctuation of $T$. urticae during 2011, but in the second season recorded significant negative effects for the tested factors, respectively. While the mean percentages of relative humidity had insignificant positive effect in both seasons.

b) A. craccivora: These results in Table (2) revealed insignificant positive and negative effects of (DMT) on the mean number of $A$. craccivora population throughout both seasons where $\left(\mathrm{r}_{1}=0.3974\right.$ and -0.5895) during 2014 and 2015, respectively, while (DMRH) had insignificant positive effect in both seasons where $\left(r_{2}=0.3397\right.$ and 0.2673$)$ respectively. The combined effect (C.D. \%) of these ecological factors on A. craccivora showed that these factors were responsible as both of $17.77 \%$ and $44.94 \%$ throughout both seasons, respectively. Similar trends were found by Ali et al. (2013) who studied the effect of maximum, minimum temperature and mean relative humidity on the population density of $A$. craccivora on bean and cowpea plants and found that highly positive significant correlation between population of $A$. craccivora and maximum, minimum temperature and mean relative humidity.

c) L. trifolii: The obtained results appeared that the correlation coefficient between population density of L. trifolii and mean temperature was positive and insignificant $\left(r_{1}=0.2341\right.$ and 0.4674$)$ in the two seasons, respectively (Table, 2). Whereas, the effect of relative humidity was negative and significant $\left(\mathrm{r}_{2}=\right.$ $-0.6518 *$ and $-0.6815 *)$ in the two successive seasons, respectively. The C.D. \% of these ecological factors 
was responsible as both of $45.05 \%$ and $47.7 \%$ throughout both seasons, respectively. These results are in disagreement with those obtained by Saradhi and Patnaik (2004) studied the correlation of the serpentine , L. trifolii revealed that diurnal temperatures variation were negatively correlated.

d) B. tabaci : Statistical analysis (Table, 2) revealed that the fluctuation of the immature stage $B$. tabaci populations were insignificant and significant positive correlated with $(\mathrm{DMT})$ where $\left(\mathrm{r}_{1}=0.5974\right.$ and $0.7307 *$ ) during $2014 \& 2015$ respectively. While (DMRH) showed had significant and highly significant positive and negative correlation where $\left(\mathrm{r}_{2}\right.$ $=0.7232 *$ and $-0.7463 * *$ ) in both seasons of study, respectively. The C.D. \% of these ecological factors were responsible as both of $57.62 \%$ and $61.09 \%$ throughout both seasons, respectively. These results are in agreement with those obtained by Jesus $\boldsymbol{e t} \boldsymbol{a l}$. (2009) observed a negative and non significant linear correlation between average temperatures of whitefly population.

e) $\boldsymbol{E}$. decipiens : In Table (2) the correlation coefficient between population density of E. decipiens and mean temperature was positive and insignificant $\left(r_{1}=0.4441\right.$ and 0.4209$)$ in two seasons respectively. But the correlation coefficient between population density and relative humidity was negative and insignificant ( $\mathrm{r}_{2}=\quad-0.1296$ and -0.5063 ) during 2014 and 2015 seasons, respectively. The C.D. \% of these ecological factors were responsible as both of $21.84 \%$ and $25.76 \%$ throughout both seasons, respectively. Similar trends were found by Abd- Elsamed et al.(2011) who indicated that the correlation coefficients between maximum, minimum temperature, relative humidity and the E. decipiens population, which infesting soybean plants at Diarb Nigm district, Sharkia governorate during two successive seasons 2009 and 2010, were positively insignificant, significant and highly significant during the two seasons of 2009 and 2010.

T. tabaci: The correlation coefficient between population density of $T$. tabaci and mean temperature was positive and significant $\left(\mathrm{r}_{1}=0.7210 *\right.$ and 0.7054*) in two seasons, respectively. But, the relative humidity was positive and insignificant $\left(\mathrm{r}_{2}=0.4588\right.$ and 0.3502) during 2014 and 2015 seasons, consecutively. The C.D.\% of these ecological factors were responsible as both of $52.41 \%$ and $60.85 \%$ throughout both seasons, consecutively in Table (2). These results are in agreement with those obtained by Waiganjo et al. (2008) who studied the correlation coefficients between environmental data included daily minimum, maximum atmospheric temperature, relative humidity and $T$. tabaci population, which infesting onion plants at Kenya, where results showed that the temperature had a positive correlation with thrips population and relative humidity (minimum and maximum) established significant negative correlation with thrips population increase.

Table 2. Effect of daily mean temperature (DMT) and relative humidity (DMRH) on the population of the main pests on kidney bean plants during summer seasons, 2014 and 2015 at Abo Hammad district, Sharkia governorate.

\begin{tabular}{|c|c|c|c|c|c|c|c|c|c|c|}
\hline \multirow{3}{*}{ Pests } & \multicolumn{4}{|c|}{ Simple correlation coefficient } & \multirow{2}{*}{\multicolumn{4}{|c|}{$\begin{array}{cc}\text { Partial } & \text { regression } \\
\mathbf{p}_{1} & \mathbf{p}_{2}\end{array}$}} & \multirow{2}{*}{\multicolumn{2}{|c|}{ C. D. \% }} \\
\hline & \multicolumn{2}{|c|}{$\mathbf{r}_{1}$} & \multicolumn{2}{|c|}{$\mathbf{r}_{2}$} & & & & & & \\
\hline & 2014 & 2015 & 2014 & 2015 & 2014 & 2015 & 2014 & 2015 & 2014 & 2015 \\
\hline T. urticae & $0.6701 *$ & $0.7282 *$ & $-0.6631 *$ & $-0.6559 *$ & 0.0241 & 0.0147 & 0.0261 & 0.0284 & 56.88 & 52.70 \\
\hline A.craccivora & 0.3974 & -0.5895 & 0.3397 & 0.2673 & 0.2261 & 0.0563 & 0.3066 & 0.4267 & 17.77 & 44.94 \\
\hline L. trifolii & 0.2341 & 0.4674 & $-0.6518 *$ & $-0.6815^{*}$ & 0.4883 & 0.1472 & 0.0298 & 0.0209 & 45.05 & 47.70 \\
\hline $\begin{array}{l}\text { B. Tabacci } \\
\text { (immature stages) }\end{array}$ & 0.5974 & $0.7307 *$ & $0.7232 *$ & $-0.7463 * *$ & 0.0523 & 0.0106 & 0.0119 & 0.0083 & 57.62 & 61.098 \\
\hline E. decipens & 0.4441 & 0.4209 & -0.1296 & -0.5063 & 0.1711 & 0.1972 & 0.7039 & 0.1120 & 21.84 & 25.76 \\
\hline T.tabaci & $0.7210^{*}$ & $0.7054 *$ & 0.4588 & 0.3502 & 0.0123 & 0.0153 & 0.1558 & 0.2910 & 52.41 & 60.85 \\
\hline
\end{tabular}

$\left(\mathbf{r}_{1}\right)$ simple correlation coefficient between pest population and mean temperature.

$\left(\mathrm{r}_{2}\right)$ simple correlation coefficient between pest population and mean relative humidity.

$\left(\mathrm{p}_{1}\right)$ partial regression coefficient between pest population and mean temperature.

( $p_{2}$ ) partial regression coefficient between pest population and relative humidity.

(C.D.) coefficient of determination.

* significant

** highly significant 


\section{References}

Abd Alla, Zeinab M. 1984. Studies on aphids in Sharkia region. Ph.D. Thesis Fac. Agric. Zagazig Univ., 167pp.

Abd El-Gawwad, S. A.Y. 2004. Biological, ecological and biocontrol studies on some mites. M. Sc. Thesis, Zoology Department, Fac. of Sci. for Girls, Al-Azhar Univ., 197pp.

Abd El-Gawwad, S. A.Y. 2008. Study of integrated pest management on some pests of common bean plant. Ph.D. Thesis, Zoology Department, Faculty of Science for Girls, Al-Azhar Univ., 409 pp.

Abd-Elsamed, A. A.; Al-Habshy, Aml Z. N. and Ahmed, M.A. 2011. Survey and population density of some dominant homopterous insects attacking soybean plants. J. Plant Prot. and Path., Mansoura Univ., 2 (7): 707 - 719.

Abo-zaid, S. M.M.A. 2011. Studies on the main insects and mites infesting kidney beans, Phaseolus vulgaris L. Ph.D. Thesis, plant protection Department, Faculty of Agriculture, Mansoura Univ., 195 pp.

Ali , SH. A.M.; Saleh, A.A.A. and Mohamed, Nadiae E. 2013. Aphis craccivora Koch. and predators on faba bean and cowpea in newly reclaimed areas in Egypt. Agric. Res., 91 (4): 14231438.

Amaar, Mona I.; EL-Refai, S. A.; Rashwan, Rania S.A. and Hegab, M. F. A. H. 2014. Population dynamics and control of certain pests infesting green bean ( Phaseolus vulgaris) at Qalubiya governorate, Egypt. Egypt. J. Agric. Res., 92 (3): 921-933.

El - Gindy, M. A. 2002. Studies on certain homopterous insect vectors of plant pathogenic diseases (Ph.D of Thesis Fac. Agric. Zagazig Univ. 263 pp.

El-Khayat, E. F.; El-Sayed, A.M.; Shalaby, F.F. and Hady, S.A. 1994. Infestation rates with Bemisia tabaci (Genn.) to different summer and winter vegetable crop plants. Ann. Agric. Sci., Moshtohor, 32(1): 577-594.

El-Sayed, A. M.; Shalaby, F. F. and Abdel-Gawad, A. A. 1991. Ecological studies on Bemisia tabaci (Gennadius)(Hemiptera-Homoptera: Aleyrodidae) infesting different host plants. 1. Fluctuation and population density of Bemisia tabaci on different host plants. Egypt. J. of Agric. Res., 69(1), 193207.

Fisher, R. A. 1950. Statistical Methods for Research Workers. Biolgical Mono-graphs and Manuals., (11 ${ }^{\text {th }}$ Ed.), Oliver and Boyed, Edinburgh and London, 354pp.

Hashem, M.S. 1997. Studies on certain insect's infesting some vegetable plants in Sharkia
Governorate. M. Sc. Thesis, Fac. Agric. Zagazig Univ., 167 pp.

Hashem, M.S. 2005. Studies on certain piercingsucking insects infesting some vegetable crops. Ph.D. Thesis, Fac. Agric. at Moshtohr Zagazig Univ., 323 pp.

Hegab, A. M.; Kelany, I. M. and EI-Maghraby, M. M. 1987. Survey of leafhoppers and planthoppers infesting maize plants by using three sampling techniques in newly reclaimed sandy areas at Salhia district, Egypt. Mina J. Agric. Res. 9 (2): 945-953.

Jesus, F. G.; Boica Junior, A. L.; Carbonel, S. A. M.; Stein, C. P. and Pitta, R. M. 2009. Infestation of Bemisia tabaci (Genn.) biotype B (Hemiptera: Aleyrodidae) and Caliothrips phaseoli(Hood.) (Thysanoptera: Thripidae) in beans genotypes. Arquivos do Instituto Biologico (Sao Paulo). 76 (3): 393-399.

Mahmoud, Y.A. ; Amr, E.M. and Ebadah, I.M.A. 2011. Some Ecological Behaviors of the Leafhopper, Empoasca decipiens (Paoli) on Some Winter Plantations in Egypt. J. Basic. Appl. Sci. Res.,1(2): 88-94.

Parrella, M.P.; Jones,V.P. ; Youngman, R.R. and Lebeck, L.M. 1985. Effect of leaf mining and leaf stippling of Liriomyza spp. on photosynthetic rates of chrysanthemum. Ann. Entomol. Soci. America, 78: 90-93.

Piha, M.I. and Munns, D. N. 1987. Nitrogen fixation capacity of field grown bean compared to other grain legumes. Agronomy Journal, 79: 690-696.

Saleh, F. M. 2011. Effect of certain agricultural practices and biological control on soygreen bean pests. Ph.D. Thesis, Economic Entomol. Department, Faculty of Agric., Mansoura Univ., 219 pp.

Sandsted, R. 1980. Energy inputs in snapbean production. In: Pimentel, D. (ed.), Handbook of energy utilization in agriculture. CRC Press, Inc., Boca Raton, FL, p. 127-128.

Saradahi, P.P. and Pantaik, N. C. 2004. Seasonal population fluctuations of serpentine leaf miner, Liriomyza trifolii (Burgess) in different host plants. App. Zool. Res., 15 (1): 60-63.

Schuster, D.J., and Everett, P.H. 1983. Response of Liriomyza trifolii (Diptera: Agromyzidae) to insecticides on tomato. Con. Entomol., 76: 11701174.

Snedecor, G.W. 1966. Statistical Methods Applied to Experiments in Agriculture and Biology. $4^{\text {th }} \mathrm{Ed}$. Iowa State Univ. Press, 485 pp.

Waiganjo, M.M.; Gitonga, L.M. and Mueke, J.M. 2008. Effects of weather on thrips population dynamics and its implications on the thrips pest management. Afr. J. Hort. Sci., (1): 82-90 


\section{تقلبات التعداد لأهم الآقات التى تصيب الفاصوليا وعلاقتها ببعض العوامل الجوية.}

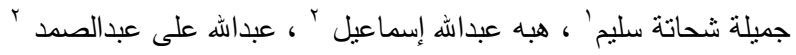

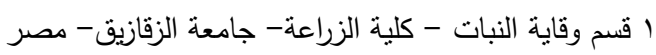

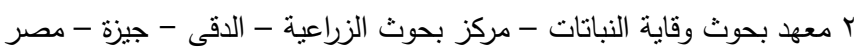

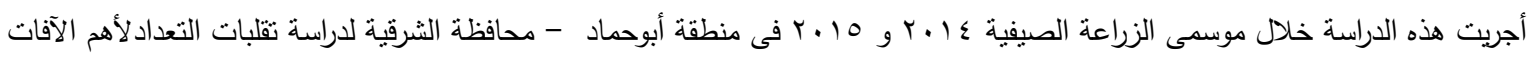

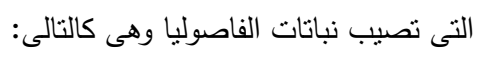

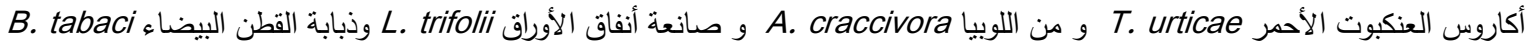

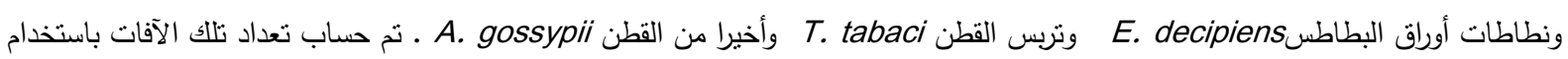

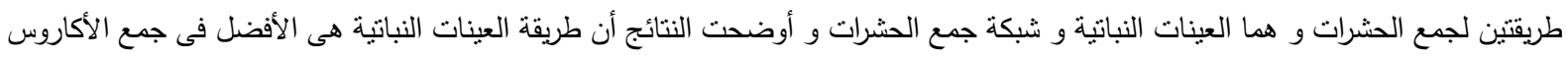

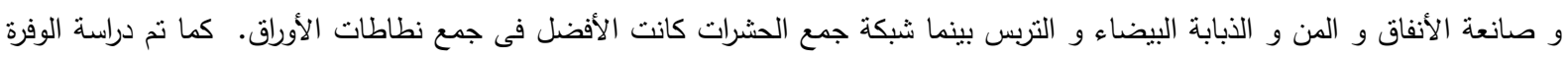

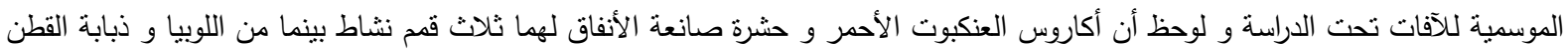

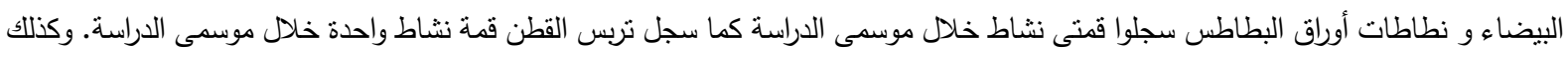

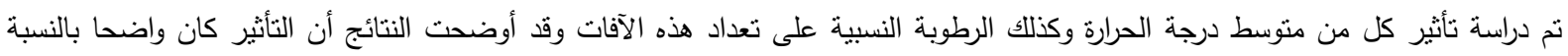

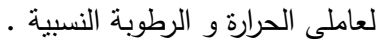

